\title{
Transfer of Chryseobacterium meningosepticum and Chryseobacterium miricola to Elizabethkingia gen. nov. as Elizabethkingia meningoseptica comb. nov. and Elizabethkingia miricola comb. nov.
}

Correspondence
Sung-Taik Lee
e_stlee@kaist.ac.kr

\author{
Kwang Kyu Kim, Myung Kyum Kim, Ju Hyoung Lim, Hye Yoon Park \\ and Sung-Taik Lee
}

\begin{abstract}
Department of Biological Sciences, Korea Advanced Institute of Science and Technology, Guseong 373-1, Yuseong, Daejeon 305-701, Korea
\end{abstract}

\begin{abstract}
The taxonomic positions of six strains (including the type strain) of Chryseobacterium meningosepticum (King 1959) Vandamme et al. 1994 and the type strain of Chryseobacterium miricola Li et al. 2004 were re-evaluated by using a polyphasic taxonomic approach.

Phylogenetic analysis, based on 16S rRNA gene sequencing, showed that the strains represent a separate lineage from the type strains of the Chryseobacterium-Bergeyella-Riemerella branch within the family Flavobacteriaceae (90.7-93.9\% similarities), which was supported by phenotypic differences. Combined phylogenetic and phenotypic data showed that C. meningosepticum and C. miricola should be transferred to a new genus, Elizabethkingia gen. nov., with the names Elizabethkingia meningoseptica comb. nov. (type strain, ATCC $13253^{\top}=$ NCTC $10016^{\top}=$ LMG $12279^{\top}=$ CCUG $214^{\top}$ ) and Elizabethkingia miricola comb. nov. (type strain, DSM $14571^{\top}=\mathrm{JCM} 11413^{\top}=$ GTC $862^{\top}$ ) proposed.
\end{abstract}

The genus Chryseobacterium was first described during reclassification of members of the genus Flavobacterium on the basis of rRNA cistron similarity studies (Vandamme et al., 1994; Bernardet et al., 1996). At that time the genera Chryseobacterium (including six species previously considered Flavobacterium species, Chryseobacterium balustinum, Chryseobacterium gleum, Chryseobacterium indologenes, Chryseobacterium indoltheticum, Chryseobacterium meningosepticum and Chryseobacterium scophthalmum), Bergeyella (including a single species, Bergeyella zoohelcum, previously considered a Weeksella species) and Riemerella (including a single species, Riemerella anatipestifer, long considered a Moraxella species) composed a separate rRNA branch of the family Flavobacteriaceae in rRNA superfamily V. Although 'Chryseobacterium proteolyticum' (Yamaguchi \& Yokoe, 2000), Chryseobacterium defluvii (Kämpfer et al., 2003), Chryseobacterium joostei (Hugo et al., 2003), Chryseobacterium miricola (Li et al., 2003) and Riemerella columbina (Vancanneyt et al., 1999) have been described since then, the

Published online ahead of print on 14 January 2005 as DOI 10.1099/ ijs.0.63541-0.

Abbreviation: CBR, Chryseobacterium-Bergeyella-Riemerella.

The GenBank/EMBL/DDBJ accession numbers for the 16S rRNA gene sequences of Elizabethkingia meningoseptica ATCC $13253^{\top}$ and Elizabethkingia miricola GTC $862^{\top}$ are AJ704540 and AB071953, respectively.
Chryseobacterium-Bergeyella-Riemerella (CBR) branch retains its original taxonomic position.

However, recent $16 \mathrm{~S}$ rRNA gene sequence similarity studies have revealed that the genus Chryseobacterium is genetically heterogeneous, and that C. meningosepticum and C. miricola can be readily differentiated from other Chryseobacterium species.

The aim of this study was to clarify the taxonomic positions of six strains of C. meningosepticum (King 1959) Vandamme et al. 1994 and C. miricola Li et al. 2004 within the family Flavobacteriaceae by using a polyphasic approach.

Strains used in this study are listed in Table 1. All were cultivated on nutrient agar (Difco) at $28^{\circ} \mathrm{C}$ except the two Riemerella strains, which were cultivated on trypticase soy agar (TSA; BBL) at $37^{\circ} \mathrm{C}$ microaerobically. For analysis of fatty acids, all strains were cultivated on TSA for $24 \mathrm{~h}$ for direct comparison.

The Gram reaction was performed as described by Gerhardt et al. (1994). Cell morphology was observed under a phasecontrast microscope $(1000 \times$ magnification; Nikon), with cells grown for 3 days on nutrient agar. Flexirubin-type pigment was detected with $20 \% \mathrm{KOH}$ according to the method of Fautz \& Reichenbach (1980). Oxidase activity was tested using Bactident-Oxidase strips (Merck) and catalase activity was tested using $3 \% \mathrm{H}_{2} \mathrm{O}_{2}$. Growth was 
Table 1. Strains investigated and their sources of isolation

Abbreviations: ATCC, American Type Culture Collection, Manassas, VA, USA; CCUG, Culture Collection of the University of Göteborg, Sweden; CIP, Collection of the Institute Pasteur, Paris, France; DSMZ, Deutsche Sammlung von Mikroorganismen und Zellkulturen, Braunschweig, Germany; JCM, Japan Collection of Microorganisms, Institute of Physical and Chemical Research (RIKEN), Saitama, Japan; KCTC, Korean Collection for Type Cultures, Daejeon, Korea; LMG, Culture Collection, Laboratorium voor Microbiologie, Ghent University, Belgium; NCTC, National Collection of Type Cultures, London, UK.

\begin{tabular}{|c|c|c|}
\hline Strain (former name) & Other designation(s) & Isolation \\
\hline $\begin{array}{l}\text { E. meningoseptica ATCC } 13253^{\mathrm{T}} \\
\text { (C. meningosepticum) }\end{array}$ & NCTC $10016^{\mathrm{T}}$, LMG $12279^{\mathrm{T}}$, CCUG $214^{\mathrm{T}}$ & Spinal fluid, MA, USA \\
\hline $\begin{array}{l}\text { E. meningoseptica ATCC } 13254 \\
\text { (C. meningosepticum) }\end{array}$ & NCTC 10585 & Blood, FL, USA \\
\hline $\begin{array}{l}\text { E. meningoseptica ATCC } 13255 \\
\text { (C. meningosepticum) }\end{array}$ & NCTC 10586 & Spinal fluid and throat, South CA, USA \\
\hline $\begin{array}{l}\text { E. meningoseptica ATCC } 49470 \\
\text { (C. meningosepticum) }\end{array}$ & AmMS 250 & Clinical specimen \\
\hline $\begin{array}{l}\text { E. meningoseptica ATCC } 51720 \\
\text { (C. meningosepticum) }\end{array}$ & LMG 12883, CCUG 26117 & Blood, Göteborg, Sweden \\
\hline E. miricola DSM $14571^{\mathrm{T}}$ (C. miricola) & JCM $11413^{\mathrm{T}}$, GTC $862^{\mathrm{T}}$ & Condensation water \\
\hline $\begin{array}{l}\text { E. miricola ATCC } 33958 \\
\text { (C. meningosepticum) }\end{array}$ & & Contaminated enzyme \\
\hline C. balustinum KCTC $2903^{\mathrm{T}}$ & NCTC $11212^{\mathrm{T}}$, ATCC $33487^{\mathrm{T}}$, LMG $8329^{\mathrm{T}}$ & Blood of freshwater fish, France \\
\hline C. defluvii DSM $14219^{\mathrm{T}}$ & CIP $107207^{\mathrm{T}}$ & Activated sludge, Germany \\
\hline C. gleum KCTC $2904^{\mathrm{T}}$ & NCTC $11432^{\mathrm{T}}$, ATCC $35910^{\mathrm{T}}$, LMG $8334^{\mathrm{T}}$ & High vaginal swab, London, UK \\
\hline C. indologenes KCTC $2905^{\mathrm{T}}$ & NCTC $10796^{\mathrm{T}}$, ATCC $29897^{\mathrm{T}}$, LMG $8337^{\mathrm{T}}$ & Trachea at autopsy, USA \\
\hline C. indoltheticum KCTC $2920^{\mathrm{T}}$ & ATCC $27950^{\mathrm{T}}$, LMG $4025^{\mathrm{T}}$, CCUG $33445^{\mathrm{T}}$ & Marine mud \\
\hline C. joostei $\mathrm{LMG} 18212^{\mathrm{T}}$ & CCUG $46665^{\mathrm{T}}$ & Raw tanker milk, Ixopo II, Kwazulu-Natal, RSA \\
\hline C. scophthalmum KCTC $2907^{\mathrm{T}}$ & ATCC $700039^{\mathrm{T}}$, LMG $13028^{\mathrm{T}}$, CCUG $33454^{\mathrm{T}}$ & Gills of diseased turbot, Scotland, UK \\
\hline B. zoohelcum KCTC $2910^{\mathrm{T}}$ & NCTC $11660^{\mathrm{T}}$, ATCC $43767^{\mathrm{T}}$, LMG $8351^{\mathrm{T}}$ & Sputum, NE, USA \\
\hline R. anatipestifer KCTC $2911^{\mathrm{T}}$ & NCTC $11014^{\mathrm{T}}$, ATCC $11845^{\mathrm{T}}$, LMG $11054^{\mathrm{T}}$ & Duck blood, USA \\
\hline R. columbina LMG $11607^{\mathrm{T}}$ & CIP $106288^{\mathrm{T}}$ & Pigeon palatine cleft, Germany \\
\hline
\end{tabular}

investigated at different temperatures $\left(5,37\right.$ and $\left.42^{\circ} \mathrm{C}\right)$, and on MacConkey agar, casein agar and starch agar (Difco). Acid production tests from sugar were performed as described by Yamaguchi \& Yokoe (2000). Additional tests were performed using API 20NE, API 20E and API ZYM galleries according to the manufacturer's instructions (bioMérieux).

Fatty acid methyl esters were prepared and analysed as described by Klatte et al. (1994) using the standard Microbial Identification System (MIDI) for automated gas chromatographic analyses (Sasser, 1990; Kämpfer \& Kroppenstedt, 1996).

Isoprenoid quinones were extracted and purified as described by Tindall (1990); dried preparations were dissolved in $200 \mu \mathrm{l}$ of 2 -propanol and 1 to $10 \mu \mathrm{l}$ was separated by HPLC without further purification. Menaquinones were separated by HPLC on a COSMOSIL 5C18-MS column (nacalai tesque) at $40{ }^{\circ} \mathrm{C}$ using acetonitrile/2-propanol (65:35, v/v) as solvent (Kroppenstedt, 1982, 1985).

Chromosomal DNA was extracted and purified by using the DNeasy Tissue Kit and Genomic-tip system 100/G (Qiagen).
In vitro amplification of extracted 16S rRNA genes was performed as described by Yoon et al. (1997) with some modifications. The $16 \mathrm{~S}$ rRNA gene sequences were aligned with published sequences retrieved from EMBL by using CLUSTAL_X (Thompson et al., 1997) and edited using BioEdit (Hall, 1999). A phylogenetic tree was constructed on the basis of the neighbour-joining method (Saitou \& Nei, 1987); evolutionary distances were estimated by the method of Jukes \& Cantor (1969) using MEGA version 2.1 (Kumar et al., 2001).

DNA base composition ( $\mathrm{G}+\mathrm{C}$ content) was determined by HPLC after hydrolysis as described by Tamaoka \& Komagata (1984) and non-methylated $\lambda$ DNA (Sigma) was used as a reference standard. DNA-DNA hybridization to determine genomic relatedness was performed fluorometrically by the method of Ezaki et al. (1989) using photobiotin-labelled DNA probes and microdilution wells.

Six strains formerly classified as C. meningosepticum and the type strain of $C$. miricola formed visible colonies (diameter of $1 \cdot 0-1 \cdot 5 \mathrm{~mm}$ ) on nutrient agar within $24 \mathrm{~h}$. Good growth was observed on TSA and nutrient agar at $28-37^{\circ} \mathrm{C}$, but no growth was observed at 5 or $42^{\circ} \mathrm{C}$ after 
Table 2. Characteristics that differentiate Elizabethkingia gen. nov. from the type strains of the CBR branch

Species: 1, E. meningoseptica ( $n=5)$; 2, E. miricola $(n=2) ; 3$, C. balustinum; 4, C. defluvii; 5, C. gleum; 6, C. indologenes; 7 , C. indoltheticum; 8, C. joostei; 9, C. scophthalmum; 10, B. zoohelcum; 11, R. anatipestifer; 12, R. columbina. +, Positive; V, variable; -, negative; n, number of strains tested.

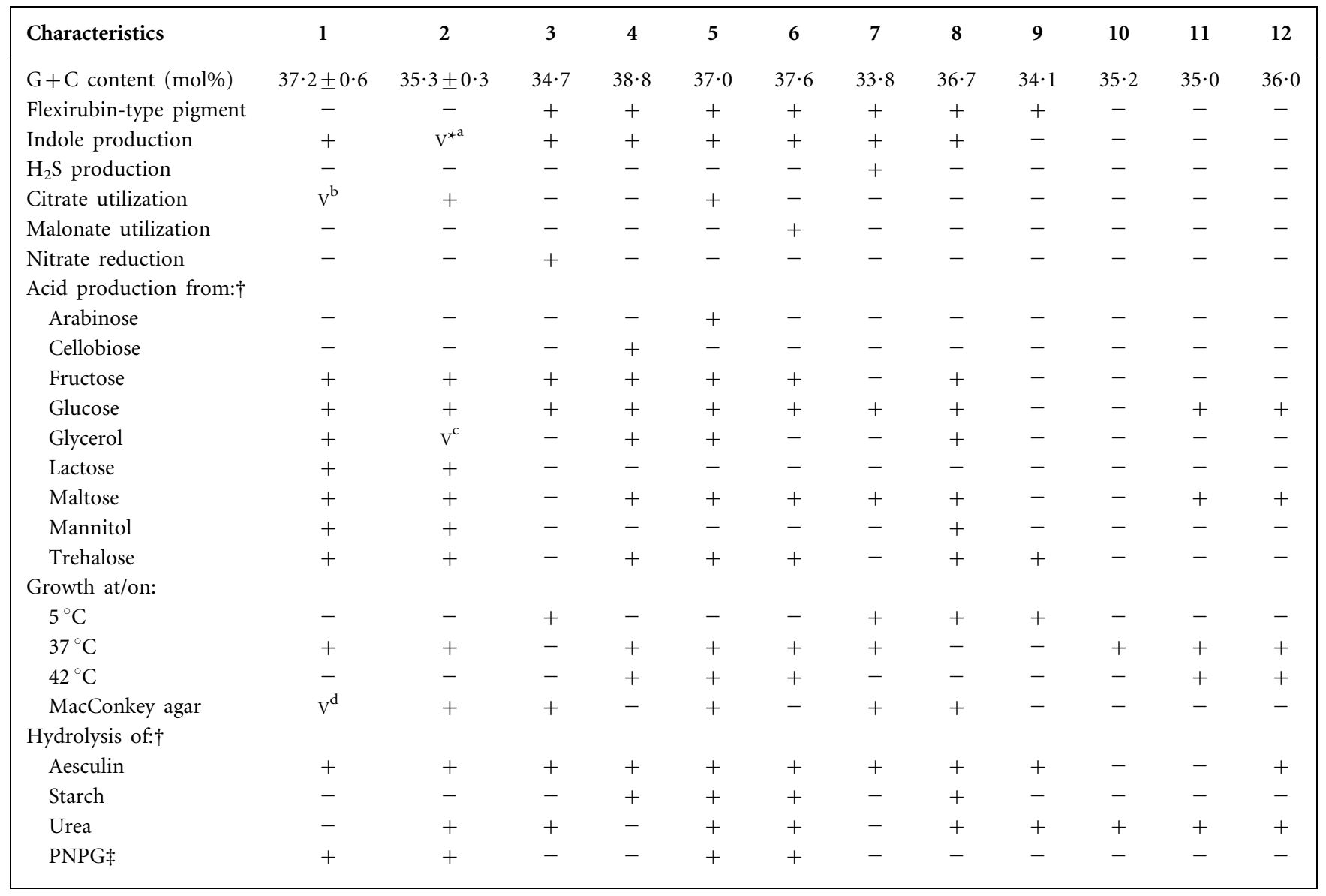

*Variable reactions are scored as: a, positive for ATCC 33958; b, positive for ATCC 13254 and ATCC 49470; c, positive for ATCC 33958; d, positive for ATCC $13253^{\mathrm{T}}$, ATCC 13255 and ATCC 51720.

$\dagger$ Acid production from raffinose, salicin, sucrose and xylose negative for all strains tested; hydrolysis of casein and gelatin positive for all strains tested.

‡PNPG, $p$-nitrophenyl- $\beta$-D-galactopyranoside.

2 weeks. Most strains could grow on MacConkey agar. Colonies were white-yellow, translucent and shiny with entire edges, becoming mucoid after 3 days incubation. Flexirubin-type pigment was not detected and acid was produced from lactose, in contrast to other Chryseobacterium species. Nitrate was not reduced as an electron acceptor and malonate was not utilized as a carbon source. As determined with the API ZYM system, a wide spectrum of substrates could be hydrolysed. Physiological and biochemical characteristics that differentiate these strains from the type strains of the CBR branch are summarized in Table 2 and Table 3.

The major quinone of the seven strains, as well as the type strains of the CBR branch, was menaquinone MK-6. The fatty acid profiles of the seven strains showed significant differences from those of the type strains of the CBR branch (Table 4). The fatty acids $15: 0$ iso, 17:0 iso $3-\mathrm{OH}$ and summed feature 4 (15:0 iso $2-\mathrm{OH}$ and/or $16: 1 \omega 7 c / t)$ were predominant and only the $C$. defluvii type strain showed similar profiles within the CBR branch.

The almost-complete 16S rRNA gene sequences of the seven strains were compared with those of representatives within the family Flavobacteriaceae. They showed 90.7-93.9\% similarity to the type strains of the CBR branch, and had quite high similarity $(97 \cdot 8-100 \%)$ with each other. In the phylogenetic tree (Fig. 1) they formed a clade that was distinct from related genera within the family Flavobacteriaceae and that could be divided into two different groups: a cluster of five strains (ATCC $13253^{\mathrm{T}}$, ATCC 13254 , ATCC 13255, ATCC 49470 and ATCC 51720), including the 
Table 3. API ZYM profiles of seven strains of Elizabethkingia gen. nov. and type strains of the CBR branch

Species: 1, E. meningoseptica ATCC $13253^{\mathrm{T}}$; 2, E. meningoseptica ATCC 13254; 3, E. meningoseptica ATCC 13255; 4, E. meningoseptica ATCC 49470; 5, E. meningoseptica ATCC 51720; 6, E. miricola DSM 14571 ${ }^{\mathrm{T}}$; 7, E. miricola ATCC 33958; 8, C. balustinum; 9 , C. defluvii; 10, C. gleum; 11, C. indologenes; 12, C. indoltheticum; 13, C. joostei; 14, C. scophthalmum; 15, B. zoohelcum; 16, R. anatipestifer; 17, R. columbina.

\begin{tabular}{|c|c|c|c|c|c|c|c|c|c|c|c|c|c|c|c|c|c|}
\hline Substrate $^{*}$ & 1 & 2 & 3 & 4 & 5 & 6 & 7 & 8 & 9 & 10 & 11 & 12 & 13 & 14 & 15 & 16 & 17 \\
\hline 2-Naphthyl butyrate & $-\dagger$ & - & - & - & - & + & + & - & - & - & - & - & - & + & - & + & + \\
\hline L-Cystyl-2-naphthylamide & + & + & + & + & - & + & + & - & - & - & + & + & + & + & - & + & + \\
\hline$N$-Benzoyl-DL-arginine-2-naphthylamide & + & + & + & + & + & + & + & - & - & - & - & - & + & + & - & - & - \\
\hline $\mathrm{N}$-Glutaryl-phenylalanine-2-naphthylamide & + & - & - & - & - & - & - & - & + & - & + & - & - & - & - & - & - \\
\hline 6-Bromo-2-naphthyl- $\alpha$-D-galactopyranoside & + & - & + & + & + & - & + & - & - & - & - & - & - & - & - & - & - \\
\hline 2-Naphthyl- $\beta$-D-galactopyranoside & - & - & - & + & - & + & - & - & - & - & - & - & - & - & - & - & - \\
\hline 2-Naphthyl- $\alpha$-D-glucopyranoside & + & + & + & + & + & + & + & + & + & + & + & + & + & + & - & + & + \\
\hline 6-Bromo-2-naphthyl- $\beta$-D-glucopyranoside & - & - & - & - & - & - & - & + & - & + & - & - & - & - & - & - & - \\
\hline 1-Naphthyl- $N$-acetyl- $\beta$-D-glucosaminide & + & + & + & + & + & + & + & + & + & + & + & + & + & + & - & - & - \\
\hline 2-Naphthyl- $\alpha$-L-fucopyranoside & + & + & - & + & - & + & + & - & - & - & - & - & - & - & - & - & - \\
\hline
\end{tabular}

${ }^{*}$ All the organisms showed positive reactions for 2-naphthyl phosphate ( $\left.\mathrm{pH} 8 \cdot 5\right), 2$-naphthyl caprylate, L-leucyl-2-naphthylamide, L-valyl-2naphthylamide, 2-naphthyl phosphate ( $\mathrm{pH} 5 \cdot 4$ ) and naphthol-AS-BI-phosphate, and showed negative reactions for 2-naphthyl myristate, naphthol-AS-BI- $\beta$-D-glucuronide and 6-bromo-2-naphthyl- $\alpha$-D-mannopyranoside.

$\dagger$ Colour intensity was measured on a scale from 0 to 5 , and interpreted as negative for values between 0 and 1 , and positive for values between 2 and 5 (Mudarris et al., 1994).

C. meningosepticum type strain, showing $98 \cdot 2-100 \% 16 \mathrm{~S}$ rRNA gene sequence similarity with each other; and a cluster of two strains (DSM $14571^{\mathrm{T}}$ and ATCC 33958), including the C. miricola type strain, showing $99 \cdot 5 \%$ similarity with each other. Five strains of $C$. meningosepticum showed $97 \cdot 8-98 \cdot 4 \%$ similarities to two strains of C. miricola.

Table 4. Cellular fatty acids of Elizabethkingia gen. nov. and type strains of the CBR branch

Species: 1, E. meningoseptica $(n=5) ; 2$, E. miricola $(n=2) ; 3$, C. balustinum; 4, C. defluvii; 5, C. gleum; 6, C. indologenes; 7, C. indoltheticum; 8, C. joostei; 9, C. scophthalmum; 10, B. zoohelcum; 11, R. anatipestifer; 12, R. columbina. $n$, Number of strains tested. Fatty acids are listed using standard abbreviations (no. of carbon atoms: no. of double bonds). Fatty acids that account for less than $1.0 \%$ of the total in all strains studied are not shown. Therefore, the percentages do not total $100 \%$. Means \pm SD are given where appropriate. tr, Trace (less than $1 \cdot 0 \%)$; ND, not detected; ECL, equivalent chain-length (i.e. the identity of the fatty acid is unknown).

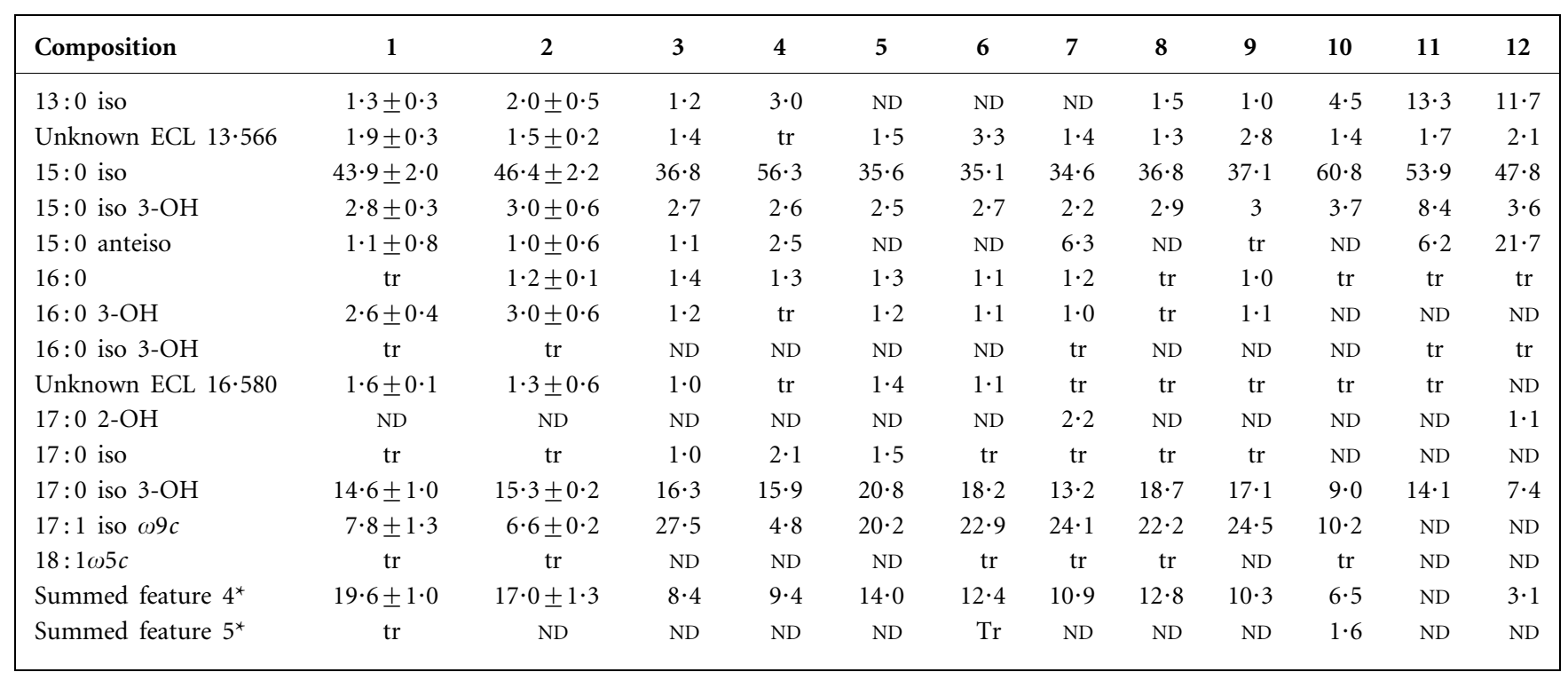

${ }^{\star}$ Summed feature 4 contains $15: 0$ iso $2-\mathrm{OH}$ and/or $16: 1 \omega 7 c / t$. Summed feature 5 contains $17: 1$ iso I and/or $17: 1$ anteiso B. 


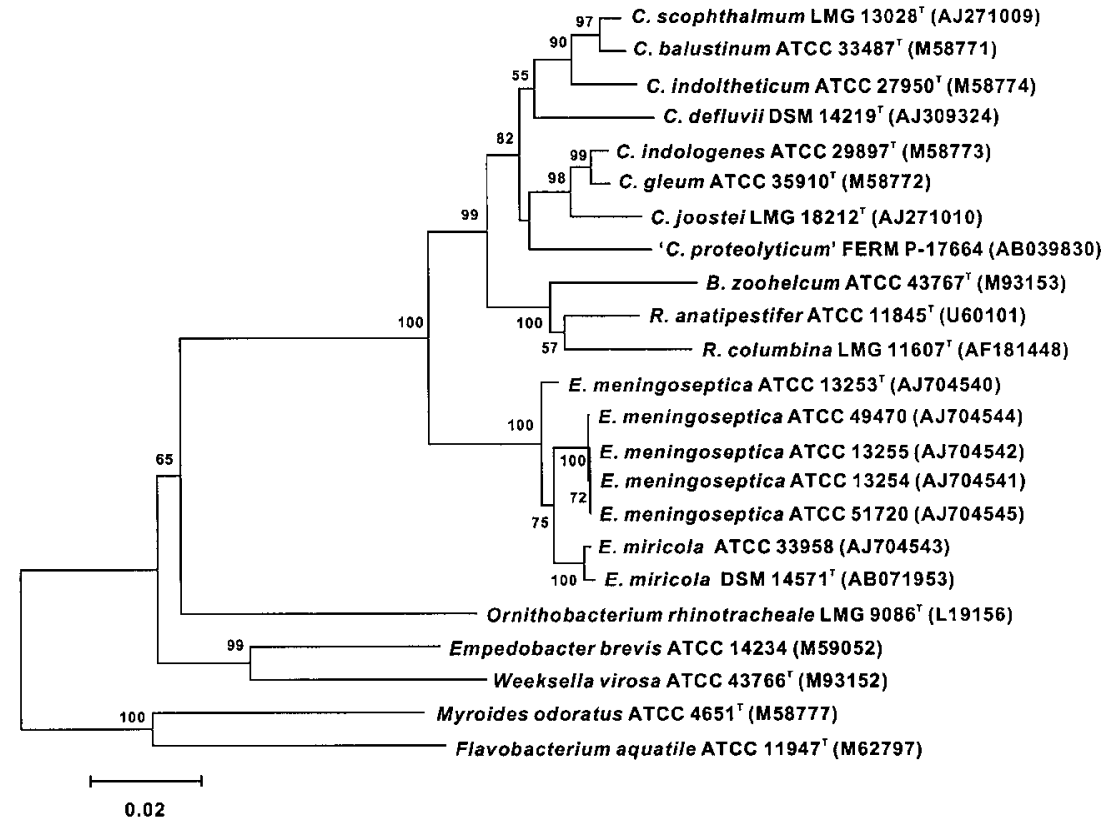

Fig. 1. $16 \mathrm{~S}$ rRNA gene sequence dendrogram obtained by distance matrix (neighbourjoining) analysis, showing the positions of the seven strains of Elizabethkingia gen. nov. Species of some genera within the family Flavobacteriaceae were used to define the root. Numbers at branching points refer to bootstrap values (1000 resamplings, only values above $50 \%$ are shown). Bar, 2 substitutions per 100 nucleotide positions. Abbreviations: C., Chryseobacterium; B., Bergeyella; E., Elizabethkingia; R., Riemerella.
The level of DNA-DNA hybridization between strain ATCC 33958 and the C. miricola type strain (84\%) demonstrated that the former belongs to $C$. miricola and not to $C$. meningosepticum as assumed previously (Stackebrandt \& Goebel, 1994) and in turn these two C. miricola strains showed levels of DNA-DNA hybridization of $23-54 \%$ to five strains of $C$. meningosepticum. By contrast, C. meningosepticum ATCC $13253^{\mathrm{T}}$ showed a DNA-DNA hybridization level of only $31-35 \%$ to the remaining four strains of $C$. meningosepticum, levels among these latter four being 90-100\%. This genetic heterogeneity using DNA-DNA hybridization was reported by Ursing \& Bruun (1987). In their studies, [Flavobacterium] meningosepticum could be divided into two genomic groups; group I (including the type strain) showed about 40-55\% DNA-DNA hybridization to group II. Subsequent studies investigating the phenotypic characterization and antimicrobial susceptibility of $[F$. meningosepticum showed no characteristics differentiating the two genomic groups (Bruun \& Ursing, 1987; Bruun, 1987). We detected no phenotypic or ecological differences among the five $C$. meningosepticum strains and therefore a proposal for a novel binomial name for the second genomovar within this species is not warranted.

Combined phylogenetic and phenotypic data show that C. meningosepticum and C. miricola should be transferred to a new genus, Elizabethkingia gen. nov., with the names Elizabethkingia meningoseptica comb. nov. and Elizabethkingia miricola comb. nov. proposed.

\section{Description of Elizabethkingia gen. nov.}

Elizabethkingia (E.liz.a.beth.kin'gi.a. N.L. fem. n. Elizabethkingia in honour of Elizabeth O. King, who first described bacteria associated with infant meningitis, notably [Flavobacterium] meningosepticum in 1959).
Cells are Gram-negative, non-motile, non-spore-forming rods $(0.5 \times 1 \cdot 0-2.5 \mu \mathrm{m})$. Good growth is observed on TSA and nutrient agar at $28-37^{\circ} \mathrm{C}$, but no growth is observed at 5 or $42^{\circ} \mathrm{C}$. Colonies are white-yellow, nonpigmented, semi-translucent, circular and shiny with entire edges. Catalase, oxidase, phosphatase and $\beta$-galactosidase activities are positive. $\mathrm{H}_{2} \mathrm{~S}$ is not produced. Casein, aesculin and gelatin are hydrolysed, but starch is not. Malonate is not utilized. Nitrate is not reduced. Acid is produced from D-fructose, D-glucose, lactose, D-maltose, D-mannitol and trehalose, but not from L-arabinose, D-cellobiose, raffinose, sucrose, salicin or D-xylose. As determined with the API ZYM system, the following

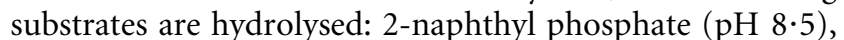
2-naphthyl caprylate, L-leucyl-2-naphthylamide, L-valyl-2naphthylamide, $N$-benzoyl-DL-arginine-2-naphthylamide, 2-naphthyl phosphate ( $\mathrm{pH} 5 \cdot 4$ ), naphthol-AS-BI-phosphate, 2-naphthyl $\alpha$-D-glucopyranoside and 1-naphthyl- $N$-acetyl$\beta$-D-glucosaminide, but the following substrates are not hydrolysed: 2-naphthyl myristate, naphthol-AS-BI- $\beta$-Dglucuronide, 6-bromo-2-naphthyl- $\beta$-D-glucopyranoside and 6-bromo-2-naphthyl- $\alpha$-D-mannopyranoside. The fatty acid profile consists largely of $15: 0$ iso, $17: 0$ iso $3-\mathrm{OH}$ and summed feature 4 (15:0 iso $2-\mathrm{OH}$ and/or $16: 1 \omega 7 c / t)$. Menaquinone MK-6 is the predominant quinone. The $\mathrm{G}+\mathrm{C}$ content of the DNA is $35 \cdot 0-38 \cdot 2 \mathrm{~mol} \%$.

The type species is Elizabethkingia meningoseptica.

\section{Description of Elizabethkingia meningoseptica comb. nov.}

Elizabethkingia meningoseptica (me.nin.go.sep'ti.ca. Gr. n. meninx, meningos meninges, membrane covering the brain; Gr. adj. septikos putrefactive; N.L. fem. adj. meningoseptica apparently referring to association of the bacterium with 
both meningitis and septicaemia, but not septic meningitis as the name implies).

Basonym: Flavobacterium meningosepticum King 1959 (Approved Lists 1980).

Cells are Gram-negative, non-motile, non-spore-forming rods $(0 \cdot 5 \times 1 \cdot 0-2 \cdot 0 \mu \mathrm{m})$. Growth on MacConkey agar is strain-dependent. Indole is produced. Urea is not hydrolysed. Acid is produced from D-fructose, ethanol, D-glucose, glycerol, lactose, D-maltose, D-mannitol and trehalose, but not from L-arabinose, D-cellobiose, raffinose, sucrose, salicin or D-xylose. As determined with the API ZYM system, the following substrates are hydrolysed: 2-naphthyl phosphate ( $\mathrm{pH} \mathrm{8.5),} \mathrm{2-naphthyl} \mathrm{caprylate,} \mathrm{L-leucyl-2-}$ naphthylamide, L-valyl-2-naphthylamide, $\mathrm{N}$-benzoyl-DLarginine-2-naphthylamide, 2-naphthyl phosphate ( $\mathrm{pH} 5 \cdot 4$ ), naphthol-AS-BI-phosphate, 2-naphthyl- $\alpha$-D-glucopyranoside and 1-naphthyl- $N$-acetyl- $\beta$-D-glucosaminide, but the following substrates are not hydrolysed: 2-naphthyl butyrate, 2-naphthyl myristate, naphthol-AS-BI- $\beta$-D-glucuronide, 6bromo-2-naphthyl- $\beta$-D-glucopyranoside and 6-bromo-2naphthyl- $\alpha$-D-mannopyranoside. The fatty acid profile consists largely of $15: 0$ iso $(43 \cdot 9 \pm 2 \cdot 0 \%), 17: 0$ iso $3-\mathrm{OH}$ $(14 \cdot 6 \pm 1 \cdot 0 \%)$ and summed feature $4(15: 0$ iso $2-\mathrm{OH}$ and/or $16: 1 \omega 7 c / t, 19 \cdot 6 \pm 1 \cdot 0 \%)$. The $\mathrm{G}+\mathrm{C}$ content of the DNA is $37 \cdot 2 \pm 0 \cdot 6 \mathrm{~mol} \%(37 \cdot 1 \mathrm{~mol} \%$ for the type strain).

The type strain is ATCC $13253^{\mathrm{T}}\left(=\right.$ NCTC $10016^{\mathrm{T}}=\mathrm{LMG}$ $12279^{\mathrm{T}}=$ CCUG $214^{\mathrm{T}}$ ).

\section{Description of Elizabethkingia miricola comb. nov.}

Elizabethkingia miricola [mi.ri'co.la. N.L. neut. n. mirum derived from mir (peace) (name of Russian space station); L. suff. - cola from L. masc. or fem. n. incola inhabitant; N.L. masc. or fem. n. miricola inhabitant of the Mir space station].

Basonym: Chryseobacterium miricola Li et al. 2004.

Cells are Gram-negative, non-motile, non-spore-forming rods $(0.5 \times 1 \cdot 0-2.5 \mu \mathrm{m})$. Good growth is observed on MacConkey agar. Colonies are very sticky on solid medium. Indole is produced. Urea is hydrolysed. Acid is produced from D-fructose, D-glucose, lactose, D-maltose, D-mannitol and trehalose, but not from L-arabinose, D-cellobiose, raffinose, sucrose, salicin or D-xylose. As determined with the API ZYM system, the following substrates are hydrolysed: 2-naphthyl phosphate ( $\mathrm{pH} 8 \cdot 5$ ), 2-naphthyl butyrate, 2-naphthyl caprylate, L-leucyl-2-naphthylamide, L-valyl-2naphthylamide, L-cystyl-2-naphthylamide, $\mathrm{N}$-benzoyl-DL-

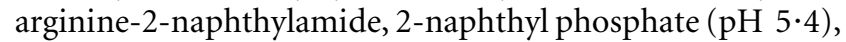
naphthol-AS-BI-phosphate, 2-naphthyl- $\alpha$-D-glucopyranoside, 1-naphthyl- $N$-acetyl- $\beta$-D-glucosaminide and 2-naphthyl- $\alpha$ L-fucopyranoside, but the following substrates are not hydrolysed: 2-naphthyl myristate, $\mathrm{N}$-glutaryl-phenylalanine2 -naphthylamide, naphthol-AS-BI- $\beta$-D-glucuronide, 6bromo-2-naphthyl- $\beta$-D-glucopyranoside and 6-bromo-2naphthyl- $\alpha$-D-mannopyranoside. The fatty acid profile consists largely of $15: 0$ iso $(46 \cdot 4 \pm 2 \cdot 2 \%), 17: 0$ iso $3-\mathrm{OH}$ $(15 \cdot 3 \pm 0 \cdot 2 \%)$ and summed feature $4(15: 0$ iso $2-\mathrm{OH}$ and/ or $16: 1 \omega 7 c / t, 17 \cdot 0 \pm 1 \cdot 3 \%)$. The $\mathrm{G}+\mathrm{C}$ content of the DNA is $35 \cdot 3 \pm 0 \cdot 3 \mathrm{~mol} \%$ ( $35 \cdot 0 \mathrm{~mol} \%$ for the type strain).

The type strain is DSM $14571^{\mathrm{T}}\left(=\mathrm{JCM} 11413^{\mathrm{T}}=\mathrm{GTC}\right.$ $\left.862^{\mathrm{T}}\right)$.

\section{Acknowledgements}

This work was supported by the Eco-Technopia-21, Ministry of Environment (grant no. 052-041-032).

\section{References}

Bernardet, J.-F., Segers, P., Vancanneyt, M., Berthe, F., Kersters, K. \& Vandamme, P. (1996). Cutting a Gordian knot: emended classification and description of the genus Flavobacterium, emended description of the family Flavobacteriaceae, and proposal of Flavobacterium hydatis nom. nov. (basonym, Cytophaga aquatilis Strohl and Tait 1978). Int J Syst Bacteriol 46, 128-148.

Bruun, B. (1987). Antimicrobial susceptibility of Flavobacterium meningosepticum strains identified by DNA-DNA hybridization. Acta Pathol Microbiol Immunol Scand [B] 95, 95-101.

Bruun, B. \& Ursing, J. (1987). Phenotypic characterization of Flavobacterium meningosepticum strains identified by DNA-DNA hybridization. Acta Pathol Microbiol Immunol Scand [B] 95, 41-47.

Ezaki, T., Hashimoto, Y. \& Yabuuchi, E. (1989). Fluorometric deoxyribonucleic acid-deoxyribonucleic acid hybridization in microdilution wells as an alternative to membrane filter hybridization in which radioisotopes are used to determine genetic relatedness among bacterial strains. Int J Syst Bacteriol 39, 224-229.

Fautz, E. \& Reichenbach, H. (1980). A simple test for flexirubin-type pigments. FEMS Microbiol Lett 8, 87-91.

Gerhardt, P., Murray, R. G. E., Wood, W. A. \& Krieg, N. R. (editors) (1994). Methods for General and Molecular Bacteriology. Washington, DC: American Society for Microbiology.

Hall, T. A. (1999). BioEdit: a user-friendly biological sequence alignment editor and analysis program for Windows 95/98/NT. Nucleic Acids Symp Ser 41, 95-98.

Hugo, C. J., Segers, P., Hoste, B., Vancanneyt, M. \& Kersters, K. (2003). Chryseobacterium joostei sp. nov., isolated from the dairy environment. Int J Syst Evol Microbiol 53, 771-777.

Jukes, T. H. \& Cantor, C. R. (1969). Evolution of protein molecules. In Mammalian Protein Metabolism, vol. 3, pp. 21-132. Edited by H. N. Munro. New York: Academic Press.

Kämpfer, P. \& Kroppenstedt, R. M. (1996). Numerical analysis of fatty acid patterns of coryneform bacteria and related taxa. Can J Microbiol 42, 989-1005.

Kämpfer, P., Dreyer, U., Neef, A., Dott, W. \& Busse, H.-J. (2003). Chryseobacterium defluvii sp. nov., isolated from wastewater. Int J Syst Evol Microbiol 53, 93-97.

King, E. O. (1959). Studies on a group of previously unclassified bacteria associated with meningitis in infants. Am J Clin Pathol 31, 241-247.

Klatte, S., Rainey, F. A. \& Kroppenstedt, R. M. (1994). Transfer of Rhodococcus aichiensis Tsukamura 1982 and Nocardia amarae Lechevalier and Lechevalier 1974 to the genus Gordona as Gordona aichiensis comb. nov. and Gordona amarae comb. nov. Int J Syst Bacteriol 44, 769-773. 
Kroppenstedt, R. M. (1982). Separation of bacterial menaquinones by HPLC using reverse phase (RP-18) and a silver loaded ion exchanger. J Liquid Chromatogr 5, 2359-2367.

Kroppenstedt, R. M. (1985). Fatty acid and menaquinone analysis of actinomycetes and related organisms. In Chemical Methods in Bacterial Systematics, no. 20 SAB Technical Series, pp. 173-199. Edited by M. Goodfellow \& D. E. Minnikin. London: Academic Press.

Kumar, S., Tamura, K., Jakobsen, I. B. \& Nei, M. (2001). MEGA2: molecular evolutionary genetics analysis software. Bioinformatics $\mathbf{1 7}$, 1244-1245.

Li, Y., Kawamura, K., Fujiwara, N., Naka, T., Liu, H., Huang, X., Kobayashi, K. \& Ezaki, T. (2003). Chryseobacterium miricola sp. nov., a novel species isolated from condensation water of space station Mir. Syst Appl Microbiol 26, 523-528.

Mudarris, M., Austin, B., Segers, P., Vancanneyt, M., Hoste, B. \& Bernardet, J.-F. (1994). Flavobacterium scophthalmum sp. nov., a pathogen of turbot (Scophthalmus maximus L.). Int J Syst Bacteriol 44, 447-453.

Saitou, N. \& Nei, M. (1987). The neighbor-joining method: a new method for reconstructing phylogenetic trees. Mol Biol Evol 4, 406-425.

Sasser, M. (1990). Identification of Bacteria by Gas Chromatography of Cellular Fatty Acids, MIDI Technical Note 101. Newark, DE: MIDI Inc.

Stackebrandt, E. \& Goebel, B. M. (1994). Taxonomic note: a place for DNA-DNA reassociation and 16S rRNA sequence analysis in the present species definition in bacteriology. Int J Syst Bacteriol 44, 846-849.
Tamaoka, J. \& Komagata, K. (1984). Determination of DNA base composition by reverse-phased high-performance liquid chromatography. FEMS Microbiol Lett 25, 125-128.

Thompson, J. D., Gibson, T. J., Plewniak, F., Jeanmougin, F. \& Higgins, D. G. (1997). The CLUSTAL_X Windows interface: flexible strategies for multiple sequence alignment aided by quality analysis tools. Nucleic Acids Res 25, 4876-4882.

Tindall, B. J. (1990). A comparative study of the lipid composition of Halobacterium saccarovorum from various sources. Syst Appl Microbiol 13, 128-130.

Ursing, J. \& Bruun, B. (1987). Genetic heterogeneity of Flavobacterium meningosepticum demonstrated by DNA-DNA hybridization. Acta Pathol Microbiol Immunol Scand [B] 95, 33-39.

Vancanneyt, M., Vandamme, P., Segers, P., Torck, U., Coopman, R., Kersters, K. \& Hinz, K.-H. (1999). Riemerella columbina sp. nov., a bacterium associated with respiratory disease in pigeons. Int J Syst Bacteriol 49, 289-295.

Vandamme, P., Bernardet, J.-F., Segers, P., Kersters, K. \& Holmes, B. (1994). New perspectives in the classification of the flavobacteria: description of Chryseobacterium gen. nov., Bergeyella gen. nov., and Empedobacter nom. rev. Int J Syst Bacteriol 44, 827-831.

Yamaguchi, S. \& Yokoe, M. (2000). A novel protein-deamidating enzyme from Chryseobacterium proteolyticum sp. nov., a newly isolated bacterium from soil. Appl Environ Microbiol 66, 3337-3343.

Yoon, J.-H., Lee, S. T., Kim, S.-B., Kim, W. Y., Goodfellow, M. \& Park, Y.-H. (1997). Restriction fragment length polymorphism analysis of PCR-amplified 16S ribosomal DNA for rapid identification of Saccharomonospora strains. Int J Syst Bacteriol 47, 111-114. 